\title{
Concept of Supervision and Supervisory Practices at Primary Level in Pakistan
}

\author{
Malik Ghulam Behlol (Correspondence Author) \\ Assistant Prof., PMAS-Arid Agriculture University, Rawalpindi, Pakistan \\ E-mail: ghulam_behlol@yahoo.com \\ Muhammad Imran Yousuf \\ Assistant Prof., PMAS-Arid Agriculture University, Rawalpindi, Pakistan
}

Qaisara Parveen

Assistant Prof., PMAS-Arid Agriculture University, Rawalpindi, Pakistan

Muhammad Munir Kayani

Assistant Prof., International Islamic University Islamabad, Pakistan

\author{
Received: April 21, 2011 Accepted: April 25, $2011 \quad$ Published: November 1, 2011 \\ doi:10.5539/ies.v4n4p28 URL: http://dx.doi.org/10.5539/ies.v4n4p28
}

\begin{abstract}
The study was conducted to find out the practices and problems of supervisors working at primary school level in Pakistan. The teachers, Headmasters, Area Education Officers, District Education Officers, Deputy District Education officers working in primary schools of Rawalpindi District were the population of the study. The questionnaire was developed, validated by the experts and pilot tested. Stratified Random sampling technique was used to collect the data of the study. The conclusions of the study reveal that the supervisors don't visit schools to facilitate teachers in solving classroom problems. They behave with them in an autocratic and authoritarian way, and the teachers are not able to share theirs problems with them. They do not believe in the concept of supervision as a process of sharing, helping, guiding, counseling and motivating teachers to solve problems which they face while teaching in classroom. Questioning and creative ideas are taken as breach of discipline. It is also revealed that the majority of the Head of institutions are not competent enough to guide their staff to perform the educational activities in the classroom. They neither delegate the responsibilities to the staff nor involve them in decision making process. As a result, the team members will not put their all out efforts in the activity and take it as burden. It is recommended that a training programme for the supervisors working at Primary level may be designed and lunched to improve their knowledge, skills and attitude to perform their duties as a facilitator, guide, motivator, helper and the leader of the team. The procedure of departmental promotion may be revised and over all competency and skills required for the performance of task as a supervisor/Headmaster/Principal should be given due importance.
\end{abstract}

Keywords: Supervision, Primary Education, Models of supervision

\section{Introduction}

Education is a process of living through continuous reconstruction of experience according to Dewey. This reconstruction process needs supervision for the smooth, effective and efficient development of human beings in physical, intellectual, aesthetic and moral domains. It is a developmental process that needs cooperative efforts for diagnosing and solving problems in the classroom and school. The supervisor is a leader charged with the responsibility of organizing a teaching force for the study of its professional problems. He does not work as an authoritative agent to threaten the teachers but as a trusted fellow to improve their performance in classroom .He is not always correct and free from mistakes like an angel who only issues commands for implementation but play a role of facilitator, helper and motivator for the solution of problems. He has to play a role of interactive than 
directive, more democrative than authoritative, more teacher centered than supervisor centered, more concrete than vague, more objective than subjective and more focused than unsystematic. It is a relationship among human beings to perform the task efficiently and effectively to improve the process of instruction. At Primary level, in Pakistan, the function of supervision has been done by the head teachers, Assistant education officer (AEO), Deputy district education officers (DDEO) and District education officers (DEO). It has been revealed through the different studies that the concerned authorities are not adequately trained to perform this function effectively, and result is high rate of drop out and poor quality of education (Behlol, 2007; Hakeem 2002). For this purpose, the researcher has decided to conduct a study to find out the practices and problems of supervisors working at primary school level and give recommendations to improve the quality of education.

\section{Objectives of the Study}

The objectives of the study were:

to find out the supervisory practices of head teachers and district supervisors at primary level

to analyse the problems of the supervisors at primary level

to give recommendations to bring some changes in the role of supervisors for improving the quality of education

\section{Review of Literature}

Education system of Pakistan has been divided into primary (1-5), middle (6-8), secondary (9-12) and tertiary levels (13-16, PhD). The primary education has been supervised by the primary school headmaster (PSH), AEO, DDEO, DEO and executive district officer (EDO). The qualification of teachers working at primary level is Matric with primary teaching certificate (PTC), F.A with certificate of teaching (CT). The current education policy recommended the qualification of Primary school teachers will not be lower than B.A, B.ED, and PTC, CT will be faced out gradually from the system. There are 156,653 Primary Schools with 465,334 teachers and 40,919 Middle Schools with 320,480 teachers (Govt. of Pakistan, 2009).

The basic function of supervision is to help the teachers to improve teaching learning process in the classroom. It is not only visiting the classroom and writing some lines in the logbook about the efficiency of the teachers, and just checking whether the work has been done according to the set plan or not. The supervisor does not work as a controller and autocratic authority of the learning process. The dictionary of education defines supervision as all efforts of designated school officials towards providing leadership to teachers and other workers in the improvement of instruction. It also involves the stimulation, and professional growth and development of teachers. It is the process of counseling, sharing and supporting teachers to improve their performance in the classroom. It is also viewed as a process that is confidential, (except in defined circumstances) positive, forward looking; primarily educational and developmental, and designed to help the individual to progress. It is different from evaluation, which is both formative and summative whereas it is a continuous process of formative nature. In assessment the trainee tries to hide what they are bad at, in educational supervision they should be comfortable about displaying it. For this purpose, he does not follow directing, telling and fault finding approach but participatory and mutual sharing technique (Wile, 1995).

Supervision should be purposeful, related to the democratic norms and total system of education. It creates leadership qualities in teachers, respects individual differences, helps individual teachers in diagnosing of teaching difficulties, and recognizes the inherent importance of an individual teacher. There are different types supervision that includes democratic, communicative, scientific, and satisfactory interpersonal, inspectoral, laissez faire and coercive. As far as functions are concerned, it involves provision of physical facilities, maintaing school discipline, recording students attendance, maintaining school accounts, preparing school budget, managing distribution of proper workload, checking safety and security of school, maintaing standard of quality education, conducting staff meeting and conferences, guiding and demonstration of lessons, preparation and provision of instructional material, supervising co-curricular activities, conducting survey, research and experiments, participating in curriculum development activities (Adam, 2002; Khan, 1999; Hick, 2002; Behlol, 2007; Peter, 2001)

There are different models of supervision, and clinical model is one of the frequently used models of supervision. The term is taken from medical science that focuses on actual treatment of patient and observation instead of experiments and laboratory study. The entire process is conducted in controlled environment. According to Tanner and Tanner (1987), clinical supervision is conducted in normal setting of classroom and involves the gathering of data from direct teaching of actual teaching-learning events and condition. Its primary goal is to improve instructions. It is in class support system designed to deliver assistance directly to teachers to bring about changes in classroom operation and teacher's behavior." According to Mosher and Purple, (1972), "clinical supervision 
demands utmost planning on the part of supervisor and supervisee. It needs knowledge about the task that is going to be performed in the classroom along with background knowledge in which that activity is going to take place."

Tanner has identified following stages of clinical supervision such as establish teacher -- supervisor relationship, planning with the teacher, planning the strategy for observation, observing instruction, analyzing the teaching learning process, planning the strategy of supervisor-teacher conference and renewed planning. The advantages of the clinical supervision are provision of objective feedback on instruction, diagnosing and solving instructional problems, assisting teacher in developing strategy to promote learning, motivating the students and managing the classroom, helping teachers to develop positive attitude towards continuous professional development, developmental in nature and helping teachers to develop positive attitude towards continuous professional development.

According to Glikman (1981), developmental supervision denotes different styles of supervisory leadership for the improvement of instruction. He explains that the leadership styles are employed in line with the knowledge of the ground realities. From ground realities he means the local environment and the facilities available in school that vary from school to school. He has pointed out directive, non-directive and collaborative styles in solving the instructional problems in working with different teachers. Directive style is appropriate for the teacher who has got low commitment and low abstract ability. Non-directive style is adopted when the teacher has got high commitment and higher abstract ability. The collaborative style is more useful with mixed ability group teachers. In this model, the supervisor creates an environment in which the teachers develop their independent thinking ability. They develop their own approaches and methods to solve the problems, which they face in the classroom. In this way the wheel of progress moves forward to improve the performance of teachers in the classroom. This model doesn't view educational activity as a static thing but considers that everything is passing from evolutionary process. It focuses on participatory approaches to solve the problems. It does not view teacher as a technician that play his role like a machine for obtaining the results. It keeps an eye on the whole person as a teacher because the actions are the outcome of his entire being. It follows scientific approach that systematically solves the significant problems.

The proponents of inspectional model believe in the authority of the supervisor who visits schools to investigate that whether work is done according to the set rules or not. He does not provide opportunity to give their opinions but straight away delineates the policy, and demands its implementation. The teachers have to follow him without questioning. Knowledge is viewed as a static entity not a changing reality. Rules are permanent and the educational standard can be improved by following rules. This model of supervision continues to follow highly mechanical and structured Role-model as received doctrine. It is lagging far behind the best theory, which conceives of teachers as a professional and supervisor, as a real leader who helps teachers to face their professional problems and continually grow in the ability to relate theory to practice.

Production Model focuses on productivity of system. The outcome of the student is considered only the sole criteria of success. School is considered industry in which the students' outcome is assessed. The method of industry, business and military is applied on education that produces zero reject system. The supervisory model is based on the behaviorist psychology that believes that teaching learning process is mechanical. The primary responsibility of the teacher is to create an environment, which provides stimulus to learner. According to skinner, teaching is merely a matter of administering the condition for the reinforcement of behavior. Once we have arranged the particular type of consequences called reinforcement, our techniques permit us to shape the behavior of organization at will.

The supervisor has to perform different roles to improve instruction in school. He has to perform the role of coordinator, planner, consultant, group leader, organizer, evaluator, motivator, technician, manager, team building, problem solving, absorbing internal and external information, decision making, communicating, morale boosting and creating confidence, resolving conflicts, creating a climate of professional growth etc. Therefore, he needs different traits in his personality such as confidence, empathy and sensitivity, enthusiasm, originality, sense of humour, sense of relative value, sincerity, resoluteness, clarity of vision, sound judgment, intelligence, communication skill, professional competency, situational context, understanding of human psychology, commitment and selflessness, hardworking, partnership working, impressive personality, intuitive ability, better listening ability, trustworthiness, assertiveness, leading innovation

\section{Methods of the Study}

\subsection{Population and Sample of the Study}

The teachers, Headmasters, AEOs, DDEOs, DEEO, EDO working in primary schools of Rawalpindi district are the population of the study. The study was delimited to the Tehsil Rawalpindi and only public schools in the Punjab Govt. were included in the study. Stratified Random sampling technique was used to collect the data of the study. 20 male and 20 female primary school teachers were randomly selected from the Tehsil Rawalpindi for the study. In 
this respect, equal weightage was given to male and female teachers working in urban and rural areas. To make the sample really representative of the population not more than two teachers were taken from the same school. Graphical presentation of the sample is as under:

\subsection{Instrument of the Study}

The questionnaire consisted of 19 items was developed and it was validated by the experts. It was pilot tested and some of the items were modified to bring clarity. The items of the questionnaire were comprised on planning of supervision, understanding the concept of supervision, lesson observation, over all atmosphere of school, attitude of supervisors, the role of senior teachers in supervising the newcomers, their interpersonal skills, mechanism of their work, the way they utilize the equipments of school, the approach of district administration for solving the problems of teachers, the schedule of their visits and its impact on the performance of teachers. The items were designed keeping in mind the status of the teachers and level of their language.

\subsection{Collection of Data}

The data were collected through questionnaire, and the researcher approached to respondents himself or through friends for filling the items of the instrument. A coding scheme was prepared and data were tabulated separately. Simple percentage formula was applied for the analyses of the data.

\section{Analyses of Data and Findings of the Study}

The analyses of the table 1 reveals that $87.5 \%$ of the Headmasters, AEOs, and DDEOs don't visit classroom to provide professional guidance to teachers whereas $12.5 \%$ of the sample group have responded that the teachers are guided and helped in the instructional activities by the supervisors. It means that the majority of the teachers working in the District Rawalpindi are performing their duties without any type of supervisory help. There is no body in or outside the school that provides help and guidance in solving the problems that the teachers face in the classroom. The leadership at primary schools has no plans to share with the teachers about their problems and difficulties.

The analyses of the table 2 reveals that $75 \%$ of the Headmasters, AEOs, and DDEOs don't have friendly, supportive and democratic attitude for the sake of professional guidance in and out of the classroom in dealing with the teachers whereas $15 \%$ have responded that their attitude is friendly, supportive and democratic. It means that the majority of the supervisors at primary level behaves with their teachers in non-democratic way and does not give any value to the opinions of the teachers at all; as a result, the teachers are not able to share their classroom difficulties with the supervisors.

The analyses of the table 3 reveals that $85 \%$ of the Headmasters don't provide any type of support in locating and provision of instructional material to facilitate their teachers in the instructional activities in the classroom whereas $7.5 \%$ responded that they facilitate regularly and $7.5 \%$ responded that they facilitate sometimes. It means that the majority of the supervisors at primary level don't facilitate their teachers to provide instructional material to them.

On the competency of the supervisors, $85 \%$ responded that they are not competent enough to guide and facilitate in solving the instructional problems that the teachers face in the classroom whereas $15 \%$ have the view that they are somewhat competent to support and guide teachers in the process of improving instruction. It means that the majority of the Head of institutions are not competent enough to guide their staff to perform the educational activities in the classroom. It indicates that we have to review the procedure of promotion of the Head of the institution that entirely basis on seniority of service.

The analyses of the table 5 reveals that $75 \%$ of the Headmasters do not conduct a meeting for the planning of academic activities at the start of academic year whereas $25 \%$ responded that they call a meeting to formulate plan for the academic activities. It is a fact that we cannot achieve the targets in time without adequate planning. For this purpose, the planning of the whole year's activities is very important. It means that the majority of the teachers are not guided at the start of academic year that how they have to proceed during their full year term. They are not able to check themselves about the pace of their work during the academic year.

The analysis of the table 6 reveals that there are 30\% supervisors who delegate the responsibilities to the suitable person for smooth functioning of school whereas $70 \%$ of the sample group does not delegate responsibilities to the appropriate members of their team. It is not possible for a single person to perform the entire working of the institution himself. He needs the cooperation of the staff to perform different activities. He has to delegates the authority to suitable person to get the work done and to guide him.

The analyses of the table 7 reveals that there are $87.5 \%$ of the supervisors who do not explain the rationale of their decisions to their team members and demand blind following from them whereas only $12.5 \%$ of the sample group 
responded that it is done by the supervisors. The team members will not put their all out efforts in the activity when they are not involved in decision making process. It means that the majority of the supervisors acts in autocratic way and get the orders implemented without any rationale and explanations.

The analysis of the table 8 reveals that $77.5 \%$ of the supervisors do not conduct meeting for the planning of academic year whereas $12.5 \%$ of the supervisors conduct meeting to plan the activities of the whole year. It means that the majority of the teachers are working without any kind of planning on their part about the instructional process in the classroom.

The analysis of the table 9 reveals that the district supervisors don't provide any type of supervisory support to the teachers and neither visit schools regularly. The sample group responded that $92.5 \%$ only visit to threaten teachers whereas only $7.5 \%$ responded that the district supervisors provide supervisory support to the teachers. It looks very difficult to improve the functioning of school without visiting them and sharing their problems. It means that they visit schools to find faults of teachers and not to help them. They entirely follow inspectorial model of supervision. It is really a very painful and undesirable performance of the administration that does not view supervision as assistance, sharing and helping to solve the problems.

The analysis of the table reveals that $75 \%$ of the respondents have the opinions that the school climate is not friendly, caring and supportive for improving the performance of the teachers in the classroom whereas $25 \%$ responded that it is friendly and caring for the personal and professional development of teachers. It shows that the supervisors are failed to create conducive environment in school for the teachers to work and grow themselves professionally.

The analysis of the table 11 reveals that the $82.5 \%$ of the supervisors don't encourage innovative and constructive ideas whereas $17.5 \%$ responded that they support and appreciate the teachers who put forward innovative ideas. Change is permanent reality of this universe; and positive changes are owed to innovative and constructive ideas. It is a frequent complaint against the school that it lacks the capacity to transform and modify itself according to the needs of the day. The supervisors instead of encouraging the innovative ideas tend to suppress them. It shows that the supervisors are completely inclined in following the trodden path instead of encouraging the staff to go for innovative ideas. As a result, the school remains far behind as compared to the forward looking pace of society.

The analysis of this table reveals that supervisors do not give importance to the views and opinions of the teachers. They are merely taken as channels of reception and transmission. $87 \%$ of the sample group is in favour of the statement whereas $15 \%$ have the opinions that they are not viewed as channels of reception and transmission. It means that the supervisors totally follow authoritative and autocratic approaches in dealing with the teachers working with them. They completely ignore the participatory, clinical and democratic supervisory role that has very positive impact on the working of institution.

The analysis of the table is about the utilization of the school equipments by the supervisor reveals that the $57.5 \%$ of the sample group have responded that school equipments are used by the supervisors (Headmasters/Principals) appropriately and judiciously whereas $42.5 \%$ of the sample group has the opinions that they are not used properly by the supervisors. It means that the majority of the supervisors are not using the school equipments properly. In this way, they are not competent enough to utilize the facilities that are available to the institution and it will be great loss of the resources of the institution.

\section{Conclusion}

The conclusion of the study reveals that the supervisors don't visit schools to find out the problems of teachers and provide supervisory support in the sollution of their problems. The teachers are working without any type of help and guidance from the internal and external supervisors. Their attitude in dealing with the staff is authoritarian and the teachers are not able to share theirs problems with them. They don't give any value to the opinions of the teachers at all. They do not believe in the concept of supervision as a process of sharing, helping, guiding, counseling and motivating teachers to solve problems which they face while teaching in classroom rather they follow fault finding and authoritative approach to get them frightened and to bully them. They practice and follow the principles of inspectoral model of supervision, which has no place in this modern time. They do not give value to the innovative and constructive ideas offered by the teachers. Questioning and creative ideas are taken as breach of discipline. They are themselves not competent enough to help and lead the team; and as a result, the teachers are unable to share their problems with them because of lack of competency and their authoritative attitude.

They also don't perform any role for locating and provision of instructional material to facilitate their teachers in the instructional activities in the classroom. It is also revealed that the majority of the Head of institutions are not competent enough to guide their staff to perform the educational activities in the classroom. It indicates that we have to review the procedure of promotion of the Head of the institution that entirely based on seniority of service. They 
don't plan the academic activities at the start of academic year. It is very difficult to achieve the targets with out any type of planning on the part of teachers.

It is also concluded that the supervisors don't delegate the responsibilities to the staff members. They try to keep all the matters under their own arm. In this way, they are not able to utilize the potential of their team effectively. They even don't involve the staff in decision making process, and they don't own the decision and they are imposed on them. The team members will not put their all out efforts in the activity when they are not involved in decision making process. They don't encourage innovative and constructive ideas that bring healthy changes in the environment of the school, and the school climate remains static and stereotyped. They are inclined in following the trodden path instead of encouraging the staff to go for innovative ideas.

It is the nature of human beings that they put their all out efforts when they are fully convinced about the importance and the need of work. The majority of the supervisors does not explain the rationale of the decisions and demand blind following from the staff working in their institutions. As a result, they take it as a burden on themselves and develop a reaction against the authority. It makes the school climate very tiring and frustrating. They are unable to perform to the level of their abilities when they are considered as a blank slate or non-living organism that are at the disposal of the Heads to be used according to his own whims and likings; and leaving no space for the expression of personal opinions. They take this situation as a threat to their autonomy and freedom.

The present trend of education and especially of higher education is sharing of the cost by the family, student, society and the Government. It has been observed the supervisors do not properly utilize the facilities and equipment available to the educational institutions. In this way, it is wastage of the resources that are available to school.

\section{Recommendations}

Following are the recommendations of the study made on the basis of findings for improving supervisory practices in our schools.

There is an urgent need of the training programme for the supervisors working at Primary level to improve their knowledge, skills and attitude to perform their duties as a facilitator, guide, motivator, helper and the leader of the team.

The procedure of departmental promotion should be revised and over all competency and skills required for the performance of task as a supervisor/Headmaster/Principal should be given due importance.

The senior teacher should be trained to provide supervisory facilities to the beginning teachers.

District supervisors may be specifically trained to work as a facilitator, motivator and supporter of the learning process.

\section{References}

A.I.O.U. (1991). Educational Management and Supervision, Code No 6502, course M.A Education, Islamabad: Allama Iqbal Open University Press.

Ali, R. (2005). Development and effectiveness of Modular teaching in Biology, Rawalpindi, Unpublished.

Tanner, D., \& Tanner, L. (1987). Supervision in Education. U.S.A: Macmillan Publishing Company.

Skinner, B. F. (1968). Technology of Teaching. New York: Appleton Century Croft Publisher.

Dewy, J. (1993). How we Think: In Mental Discipline in Modern Education. W. Kollesnick, University of Wisconsin Press.

Carl, D. G. (1981). Developmental Supervision. Alexandria, V. A. The Association.

Sergivinni, T. J., \& Starratte, R. J. (1983). Supervision: Human Perspective. New York: McGraw Hills.

Wiles, K. (1984). Supervision for Better Schools. New Delhi: Prentice Hall of India Private Limited.

Shearon, G. F., \& Cryan, J. R. (1973). Journal of Education. Vol: 50, 184-190

Burhan, R. M. (1976). Instructional Supervision: Past, Present and Future Perspective, Theory into Practice, Vol: 4.U.S.A., $180-185$

Mirick, G. A. (1918). The Elementary School Journal, Administration and Supervision. Vol: 4, 130

Blair, B. (1990). Towards Strong Relationship: Evaluation of the supervisory Trends, Educational Horizan, 68, 140-144

Burt, A. (1948). Supervision of Instruction, Peadbody Journal of Education. Vol. 25, 208-217 
Alfonso, R. J., Firth, G. R., \& Nvilee, R. F. (1975). Instructional Supervision: A behavior system. Boston: Allen and Backen.

Burton, W. H., \& Freshener, L. J. (1955). Supervision: A Social process. New York: Appleton-century-croft.

Table 1. Headmaster, AEOs and DDEOs visit classroom to provide professional guidance

\begin{tabular}{|l|c|c|c|}
\hline $\begin{array}{l}\text { Headmaster, AEOs and DDEOs visit classroom to provide } \\
\text { professional guidance }\end{array}$ & Male & Female & $\begin{array}{c}\text { Total } \\
\%\end{array}$ \\
\hline Yes & 2 & 3 & 12.5 \\
\hline No & 18 & 17 & 87.5 \\
\hline
\end{tabular}

Table 2. Friendly, supportive and democratic attitude for the sake of professional guidance in and out of the classroom

\begin{tabular}{|l|c|c|c|}
\hline $\begin{array}{l}\text { Friendly, supportive and democratic attitude for the sake of } \\
\text { professional guidance in and out of the classroom }\end{array}$ & Male & Female & $\begin{array}{c}\text { Total } \\
\%\end{array}$ \\
\hline Yes & 2 & 4 & 15 \\
\hline No & 18 & 16 & 75 \\
\hline
\end{tabular}

Table 3. Provision of instructional material from the Headmaster

\begin{tabular}{|l|c|c|c|}
\hline Headmaster provides instructional material regularly & Male & Female & $\begin{array}{c}\text { Total } \\
\%\end{array}$ \\
\hline Yes & 2 & 1 & 7.5 \\
\hline No & 16 & 18 & 85 \\
\hline Sometimes & 2 & 1 & 7.5 \\
\hline
\end{tabular}

Table 4. H.M competent enough to guide and facilitate you in solving the problems

\begin{tabular}{|l|c|c|c|}
\hline $\begin{array}{l}\text { H.M competent enough to guide and facilitate you in solving } \\
\text { the problems }\end{array}$ & Male & Female & $\begin{array}{c}\text { Total } \\
\%\end{array}$ \\
\hline Yes & 3 & 3 & 15 \\
\hline No & 17 & 17 & 75 \\
\hline
\end{tabular}

Table 5. Meeting of staff at the start of academic year for the planning of academic activities

\begin{tabular}{|l|c|c|c|}
\hline $\begin{array}{l}\text { Meeting of staff at the start of academic year for the } \\
\text { planning of academic activities }\end{array}$ & Male & Female & $\begin{array}{c}\text { Total } \\
\%\end{array}$ \\
\hline Yes & 4 & 6 & 25 \\
\hline No & 16 & 14 & 75 \\
\hline
\end{tabular}

Table 6. Delegation of responsibility to suitable staff members to improve the functioning of school

\begin{tabular}{|l|c|c|c|}
\hline $\begin{array}{l}\text { Delegation of responsibility to suitable staff members to } \\
\text { improve the functioning of school }\end{array}$ & Male & Female & $\begin{array}{c}\text { Total } \\
\%\end{array}$ \\
\hline Yes & 8 & 4 & 30 \\
\hline No & 12 & 16 & 70 \\
\hline
\end{tabular}


Table 7. Explanation and rationale of decision provided by the Headmaster

\begin{tabular}{|l|c|c|c|}
\hline Explanation and rationale of decision provided by the H.M & Male & Female & $\begin{array}{c}\text { Total } \\
\%\end{array}$ \\
\hline Yes & 2 & 3 & 12.5 \\
\hline No & 18 & 17 & 87.5 \\
\hline
\end{tabular}

Table 8. Meeting of staff at the start of academic year for the planning of academic activities

\begin{tabular}{|l|c|c|c|}
\hline $\begin{array}{l}\text { Meeting of staff at the start of academic year for the } \\
\text { planning of academic activities }\end{array}$ & Male & Female & $\begin{array}{c}\text { Total } \\
\%\end{array}$ \\
\hline Yes & 5 & 4 & 22.5 \\
\hline No & 15 & 16 & 77.5 \\
\hline
\end{tabular}

Table 9. DDEO, AEO visit schools regularly

\begin{tabular}{|l|c|c|c|}
\hline $\begin{array}{l}\text { DDEO, AEO visit school to provide supervisory assistance } \\
\text { to teachers }\end{array}$ & Male & Female & $\begin{array}{c}\text { Total } \\
\%\end{array}$ \\
\hline Yes & 2 & 1 & 7.5 \\
\hline No & 18 & 19 & 92.5 \\
\hline
\end{tabular}

Table 10. The school climate is caring, friendly and supportive

\begin{tabular}{|l|c|c|c|}
\hline The school climate is caring, friendly and supportive & Male & Female & $\begin{array}{c}\text { Total } \\
\%\end{array}$ \\
\hline Yes & 4 & 6 & 25 \\
\hline No & 16 & 14 & 75 \\
\hline
\end{tabular}

Table 11. Constructive and innovative ideas are highly valued, shared and implemented.

\begin{tabular}{|l|c|c|c|}
\hline $\begin{array}{l}\text { Constructive and innovative ideas are highly valued, shared } \\
\text { and implemented }\end{array}$ & Male & Female & $\begin{array}{c}\text { Total } \\
\%\end{array}$ \\
\hline Yes & 3 & 4 & 17.5 \\
\hline No & 17 & 16 & 82.5 \\
\hline
\end{tabular}

Table 12. Supervisors view teachers as channels of reception and transmission.

\begin{tabular}{|l|c|c|c|}
\hline $\begin{array}{l}\text { The supervisors view teachers as channels of reception and } \\
\text { transmission }\end{array}$ & Male & Female & $\begin{array}{c}\text { Total } \\
\%\end{array}$ \\
\hline Yes & 16 & 18 & 85 \\
\hline No & 4 & 2 & 15 \\
\hline
\end{tabular}

Table 13. The facilities and equipments of school are used properly and judiciously

\begin{tabular}{|l|c|c|c|}
\hline $\begin{array}{l}\text { The facilities and equipments of school are used properly } \\
\text { and judiciously }\end{array}$ & Male & Female & $\begin{array}{c}\text { Total } \\
\%\end{array}$ \\
\hline Yes & 8 & 15 & 57.5 \\
\hline No & 12 & 5 & 42.5 \\
\hline
\end{tabular}

